\title{
PRE- AND PERINATAL FACTORS ASSOCIATED WITH WEIGHT GAIN AMONG PRESCHOOL CHILDREN ENROLLED AT DAY CARE CENTERS
} Associação entre fatores pré e perinatais e padrão de ganho de peso em pré-escolares de centros de educação infantil

\author{
Nykholle Bezerra Almeida ${ }^{(1)}$, Rísia Cristina Egito de Menezes ${ }^{a}$ (1), \\ Kariny dos Santos Sobral ${ }^{a} \mathbb{D}$, Jaqueline Fernandes Gomes ${ }^{a} \mathbb{D}$, \\ Giovana Longo-Silva ${ }^{a}$ (D), Jonas Augusto Cardoso da Silveira ${ }^{a, *}$
}

\section{ABSTRACT}

Objective: To identify the factors associated with excessive weight gain in preschool children enrolled at daycare centers in a capital of the Northeast region of Brazil.

Methods: It was a cross-sectional study conducted at the five daycare centers located in the city's district of most socioeconomic vulnerability. The study included 326 preschool children (17 to 63 months old) from both genders. The dependent variable was the conditional weight gain (CWG), that represents how much a child, according to their gender, deviated from their peers in relation to the expected weight gain, given sample's birthweight, gender, and age at the survey. Univariate tests (t-test and analysis of variance) were used to compare CWG means according to environmental and biological factors, considering the independent variables with $p<0.20$ as electable for the multiple linear regression model. In the final model, variables with $p<0.05$ or that contributed to the model adjustment were kept.

Results: Children's mean age was $45.4 \pm 9.9$ months, and $53.4 \%$ of the sample consisted of boys. The prevalence of overweight was $7 \%$. In the multivariable linear regression model, it was possible to identify that the following factors were associated with excessive weight gain among preschool children: less than six prenatal care visits (0.36 SD [95\%Cl 0.13-0.60]), not rooming-in in the postpartum period ( 0.30 SD [95\% Cl 0.03-0.58]), and never breastfed (0.44 SD [95\%Cl 0.06-0.81]).

Conclusions: Inadequate prenatal (appointments) and perinatal care (mother-infant rooming-in and absence of breastfeeding) were associated with excessive weight gain among low-income preschool children.

Keywords: Child, preschool; Weight gain; Obesity; Child day care centers; Prenatal care; Breast feeding.

\section{RESUMO}

Objetivo: Identificar fatores associados com o ganho ponderal excessivo entre pré-escolares de Centros de Educação Infantil (CEIs) em uma capital do Nordeste brasileiro.

Métodos: Estudo transversal realizado em cinco CEls situados no distrito de maior vulnerabilidade socioeconômica do município. Foram incluídas 326 crianças de ambos os sexos, com idades entre 17 e 63 meses. A variável dependente foi a evolução ponderal condicional (EPC), a qual representa o quanto uma criança desviou do ganho de peso esperado em relação a seus pares, de acordo com o sexo, o peso ao nascer e a idade no inquérito. Análises univariadas (teste $t$ de Student ou análise de variância) foram utilizadas para comparar as médias da EPC em função de fatores biológicos e ambientais, considerando como elegíveis para o modelo múltiplo de regressão linear as variáveis independentes com $p<0,20$; permaneceram no modelo final aquelas que apresentaram $p<0,05$ ou que contribuíram no ajuste do modelo.

Resultados: A média de idade foi de 45,4 $\pm 9,9$ meses e 53,4\% eram meninos. A prevalência de excesso de peso foi de $7 \%$. No modelo múltiplo de regressão linear, identificamos que realizar menos de 6 consultas pré-natal ( $\mathrm{DP}=0,36$; IC95\% 0,13-0,60), não ter permanecido em alojamento conjunto no pós-parto ( $\mathrm{DP}=0,30$; IC95\% 0,03-0,58) e nunca ter sido amamentado ( $D P=0,44$; IC95\% 0,06-0,81) foram fatores associados com o ganho excessivo de peso entre pré-escolares. Conclusões: A inadequação dos cuidados pré-natal (consultas) e perinatal (não permanecer em alojamento conjunto e ausência da amamentação) se associaram com o ganho excessivo de peso entre pré-escolares de baixa renda.

Palavras-chave: Pré-escolar; Ganho de peso; Obesidade; Creches; Cuidado pré-natal; Aleitamento materno. 


\section{INTRODUCTION}

Over the last five decades, Brazilian society has been experiencing a process of food and nutrition transition, with a significant decrease in the prevalence of malnutrition along with an increase in the prevalence of obesity, currently characterized as one of the leading public health problems. Such changes in nutritional profile were so significant that they affected not only adults but also children. ${ }^{1}$

Obesity, which was initially more common in economically developed regions, such as the southeastern and southern regions, was widespread in low-income regions, especially in the Northeast. ${ }^{1}$ A study based on data from national health surveys in the Brazilian population identified, between 1986 and 2006, the prevalence of overweight in preschool children going from 3 to $7.8 \%$; however, the highest prevalence increase occurred in the Northeast Region, where overweight jumped from 1.6 to $7.2 \%$ between 1989 and 2006 , representing a relative increase of $350 \%{ }^{2}$ In Alagoas (2005-2006), about $9.7 \%$ of children under five years of age were obese. ${ }^{3}$

Considering family and society behavioral aspects, excessive weight gain in childhood is related to the adoption of unhealthy eating practices, such as early interruption of exclusive breastfeeding $(\mathrm{EBF})$ through the introduction of infant formulas and/or low nutritional quality infant foods (e.g. ultraprocessed foods and sugary drinks), with subsequent total weaning of breast milk. ${ }^{4,5}$ Such phenomena can stem from issues such as the lack of prenatal guidance or even its poor quality resulting from fragile bond between professionals and individuals. From a broader perspective, the historical role of the food industry in cultural change about infant feeding in early childhood is highlighted, through communication strategies directed at both the general population and health professionals. ${ }^{5,6}$

Therefore, the objective of this study was to evaluate the pattern of weight gain and factors associated with deviations above the expected for age, sex and birth weight among preschool children from a region of high socioeconomic vulnerability in the city of Maceió, Alagoas.

\section{METHOD}

Cross-sectional study conducted at the five day-care centers (DCC) of the seventh health district of Maceió, Alagoas, region of greatest socioeconomic vulnerability of the municipality, entitled "Nutritional situation of children in public day care centers and actions related to food and nutrition in primary care: an intersectoral approach". All children enrolled in the DCCs aged 17 to 63 months and without physical/motor or intellectual disabilities were considered eligible.

Data collection was made between March and July 2014 by previously trained field teams, with structured and pre-coded questionnaires on biological, dietary, maternal and socioeconomic variables applied to mothers or guardians.

Anthropometry of children under 2 years old or weighing up to $15 \mathrm{~kg}$ was made on digital pediatric scale (BP Baby, Filizola, Sáo Paulo, SP, Brazil) and using a $120 \mathrm{~cm}$ anthropometric ruler with movable cursor, graduated at $0.5 \mathrm{~cm}$. Children older than 2 years or weighing more than $15 \mathrm{~kg}$ were weighed on a digital scale (Plenna, São Paulo, SP, Brazil) and had their height measured on a portable stadiometer (accuracy of $0.1 \mathrm{~cm}$ ) (Alturaexata, Belo Horizonte, MG, Brazil). Anthropometric indicators - Z-score for weight for age (ZWA) and body mass index for age (ZBMI) - were calculated based on the World Health Organization's (WHO) growth curve macro. ${ }^{7}$

The child's weight gain pattern was analyzed based on the conditional weight gain variable (CWG), that is, the standardized residual of gender-specific linear regression models, with the difference between ZWA at birth and at the moment of survey being the dependent variable, and the ZWA of birth weight and current age as independent variable. It represents how much children deviated from the expected weight gain for their age, sex and birth weight, and this variation is expressed as standard deviations (SD). Thus, positive CWG values represent children who gained more weight than expected in relation to their peers. This formulation corrects problems such as the mean regression effect, different ages at the time of research, and collinearity of repeated measures. ${ }^{5,8}$

Biological factors were gender, age, nutritional status and anemia; perinatal factors were birth weight, gestational age, disease at birth and reasons for hospitalization (preventable, non-preventable diseases or absence of diseases). ZBMI was used to sort nutritional status with the following cutoff points: normal weight $(\leq+1 \mathrm{SD})$, risk of overweight $(>+1 \mathrm{SD}$ and $<+2 \mathrm{SD})$ and overweight $(\geq+2 \mathrm{SD}$ ). Anemia (hemoglobin $<11 \mathrm{mg} / \mathrm{dL}$ ) was defined according to the WHO's recommendations, ${ }^{9}$ and birth disease was characterized as the presence/absence of any birth-related disease.

Maternal variables included: mother's age, education, number of prenatal appointments, desire for pregnancy, and primiparity. Regarding socioeconomic factors, the following were considered: number of siblings $<5$ years, monthly per capita income (MPCI) $<\mathrm{R} \$ 70.00$, and grant of government assistance. For the categorization of the MPCI, the extreme poverty 
cutoff at the time of the research ${ }^{10}$ was used. For dietary data, we analyzed breastfeeding at some point in life, time of exclusive breastfeeding (EBF), time of breastfeeding $(\mathrm{BF})$, age of introduction of sugary drinks, and age of introduction of ultraprocessed foods. Finally, the group (nursery I and II /kindergarten I) and the school shift (morning, afternoon, full-time) were also included.

Since the outcome variable had a normal distribution, the CWG means were compared according to the independent variable categories by Student's t-test or analysis of variance (ANOVA). The independent variables with $\mathrm{p}<0.20$ were considered eligible for the multiple linear regression model, being kept in the model those with $\mathrm{p}<0.05$ or that contributed to the model adjustment. As for the final model, the diagnostic graphs showed that the standardized residuals were distributed randomly and homogeneously on the basis of values predicted by the equation and the independent variables analyzed; Also, no collinearity was observed, as assessed by the variance inflation factor (VIF). Analyses were performed in Stata/SE 15.1 (StataCorp LP, College Station, TX, USA).

This project was funded by the State of Alagoas Research Support Foundation (FAPEAL; Process 60030000692/2013) and approved by the Human Research Ethics Committee of Universidade Federal do Alagoas (CAAE 18616313.8.0000.5013). The research was supported by the municipal department of health and by the directors of the DCCs, and only children whose legal guardians signed the informed consent form were included in the sample.

\section{RESULTS}

Among the 366 eligible children, seven were not recruited due to non-signing of the informed consent form by their guardians $(n=2)$ and absence on interview days $(n=5)$. After excluding subjects whose information on birth weight or in the moment of survey was missing $(n=33)$, the sample was formed by 326 children.

Of these, $53.4 \%$ were males and $83.1 \%$ were older than 36 months, with a mean of $45.4 \pm 9.9$ months. Respectively, 12.3 and $7.0 \%$ of preschool children were at risk of overweight and excess weight, and $44.3 \%$ of them were anemic (Table 1 ). Regarding gestational age, $86.2 \%$ had been born at term ( $\geq 37$ weeks), $92.3 \%$ had received breastfeeding at some point in their lives, and only $6.0 \%$ had received breastfeeding for 180 days or more. As for the introduction of ultraprocessed foods, $77.3 \%$ of mothers reported introducing before 6 months of age (Table 2 ).
As for mothers, the mean age was $24.8 \pm 6.7$ years, $23 \%$ had gone to less than 6 prenatal consultations, and about $13.8 \%$ had had less than four years of study. Socioeconomic data were: $8.4 \%$ had income less than or equal to $\mathrm{R} \$ 70$, and $76.6 \%$ reported receiving a benefit from the government (Table 3).

In the univariate analysis, children who had never been breastfed $(\mathrm{CWG}=0.40 \pm 0.9 ; \mathrm{p}=0.033)$, who had been born with gestational age $<37$ weeks $(C W G=0.27 \pm 0.9$; $\mathrm{p}=0.050$ ), whose mothers had $<6$ prenatal consultations (CWG $=0.26 \pm 1.0 ; \mathrm{p}=0.008)$, and whose monthly per capita income was $>\mathrm{R} \$ 70(\mathrm{CWG}=0.03 \pm 1.0 ; \mathrm{p}=0.097)$ had above-average weight gain compared to their peers (Tables 2 and 3). Finally, in the multiple model (Table 4) adjusted for MPCI, mother's age at birth and child's height, we found that fewer than six prenatal appointments $(\mathrm{SD}=0.36$; 95\%CI 0.13-0,60), having never been breastfed $(\mathrm{SD}=0.44 ; 95 \% \mathrm{CI} 0.06-0.81)$, and not having stayed in joint postpartum rooming $(\mathrm{SD}=0.30 ; 95 \% \mathrm{CI}=0.03-0,58)$ were associated with excessive weight gain.

\section{DISCUSSION}

The objective of this study was to evaluate the factors associated with excessive weight gain among preschoolers in a region of high social vulnerability of a municipality located in the State with the worst performance in the country's human development index. ${ }^{11}$ We identified that children who had never been breastfed, did not stay in a postpartum room with their mother, and whose mothers had less than six prenatal appointments had greater weight gain than their peers, and the fact that they had never received milk was the factor with most effect magnitude. This paper reinforces the paradigm shift in the relationship between nutritional status and breastfeeding. Overall, even in low-income Brazilian populations, the absence of breastfeeding no longer poses a risk for malnutrition but for overweight.

These findings were interpreted in light of the contextual model of risk factors for obesity in the first thousand days of life, proposed by Baidal et al. ${ }^{12}$ Therefore, from the gaps identified in this systematic review, ${ }^{12}$ the main contributions of this research refer to the effect of community factors (availability and utilization of health services) and mothers' behavior (dietary style) on children's weight gain. More specifically, our results reinforce the deleterious effect of the absence of breastfeeding on excessive weight gain, in addition to being one of the few studies that have investigated and established the relationship between pre and perinatal care (consultations and rooming-in care) on the adiposity levels of children. 
It is understood that there is a chronological sequence of factors in their contribution to childhood obesity. Starting with prenatal care, smaller number of appointments than the recommendation by the Ministry of Health may have limited the opportunities for health teams to work with pregnant women and prepare them for breastfeeding, also compromising access to information about the benefits and myths of breastfeeding and guidelines for healthy complementary eating.

Another important aspect related to the performance of health services in primary care is the formation of groups of

Table 1 Characteristics of preschool children attending day care centers in a capital of northeastern Brazil, 2014.

\begin{tabular}{|l|l|l|l|l}
\hline Characteristics & $\mathrm{n}$ & $\%$ & Mean CWG (SD) & p-value
\end{tabular}

Gender

\begin{tabular}{|c|c|c|c|c|}
\hline Female & 152 & 46.6 & $0.00(1.0)$ & \multirow{2}{*}{0.998} \\
\hline Male & 174 & 53.4 & $0.00(1.0)$ & \\
\hline \multicolumn{5}{|l|}{ Age } \\
\hline$<36$ months & 55 & 16.9 & $0.00(1.0)$ & \multirow{2}{*}{0.949} \\
\hline$\geq 36$ months & 271 & 83.1 & $0.00(1.0)$ & \\
\hline \multicolumn{5}{|l|}{ Nutritional status } \\
\hline Normal weight & 263 & 80.7 & $-0.32(0.7)$ & \multirow{3}{*}{$<0.001^{*}$} \\
\hline Risk of overweight & 40 & 12.3 & $0.99(0.5)$ & \\
\hline Overweight & 23 & 7.0 & $1.96(0.6)$ & \\
\hline \multicolumn{5}{|l|}{ Birth weight } \\
\hline$<2.5 \mathrm{~kg}$ & 30 & 9.2 & $0.09(0.9)$ & \multirow{2}{*}{0.574} \\
\hline$\geq 2.5 \mathrm{~kg}$ & 296 & 90.8 & $0.00(1.0)$ & \\
\hline \multicolumn{5}{|l|}{ Gestational age } \\
\hline$<37$ weeks & 45 & 13.8 & $0.27(1.1)$ & \multirow{2}{*}{0.050} \\
\hline$\geq 37$ weeks & 281 & 86.2 & $-0.04(0.9)$ & \\
\hline \multicolumn{5}{|l|}{ Disease at birth } \\
\hline Yes & 41 & 12.6 & $0.13(0.9)$ & \multirow{2}{*}{0.354} \\
\hline No & 285 & 87.4 & $-0.01(1.0)$ & \\
\hline \multicolumn{5}{|l|}{ Reasons for hospitalization } \\
\hline Never hospitalized & 237 & 72.7 & $0.00(0.9)$ & \multirow{3}{*}{$0.087^{*}$} \\
\hline Preventable diseases & 66 & 20.2 & $-0.14(1.0)$ & \\
\hline Non-preventable diseases & 23 & 7.1 & $0.39(1.1)$ & \\
\hline \multicolumn{5}{|l|}{ Anemia } \\
\hline Yes & 144 & 44.3 & $0.03(1.0)$ & \multirow{2}{*}{0.552} \\
\hline No & 188 & 55.7 & $0.03(0.9)$ & \\
\hline \multicolumn{5}{|l|}{ Group } \\
\hline Maternal I & 61 & 18.7 & $-0.03(1.0)$ & \multirow{3}{*}{$0.953^{*}$} \\
\hline Maternal II & 150 & 46.0 & $0.01(1.0)$ & \\
\hline Jardim I & 115 & 35.3 & $0.00(0.9)$ & \\
\hline \multicolumn{5}{|l|}{ School shift } \\
\hline Morning & 178 & 54.6 & $0.00(0.9)$ & \multirow{3}{*}{$0.486^{*}$} \\
\hline Afternoon & 86 & 26.4 & $0.09(1.1)$ & \\
\hline Full time & 62 & 19.0 & $-0.10(1.0)$ & \\
\hline
\end{tabular}

CWG: conditional weight gain; SD: standard deviation; *ANOVA. 
mothers and pregnant women. The low attendance to prenatal consultations may indicate absence of such activities, which are fundamental to build maternal self-efficacy to breastfeed, as it is determined by personal and vicarious experiences, encouragement by others and emotional state. ${ }^{13}$ The fundamental role of joint postpartum rooming is highlighted as a space for strengthening mother-child bond, facilitating the onset of breastfeeding and avoiding early (and often unnecessary) introduction of infant formulas, which can also be classified as ultraprocessed food, and other foods. ${ }^{14}$

It is noteworthy that having stayed in rooming-in care, attended more than six prenatal appointments and never having breastfed the child were factors independently associated with excessive weight gain (afterwards, terms of interaction between factors were tested, but no association was found). Therefore, our hypothesis to justify such associations is related to the construction of positive support networks, both by other women and by professionals involved in the health care of pregnant women.

The importance of prenatal care for the promotion of adequate and healthy child nutrition was demonstrated in a cohort conducted in Recôncavo da Bahia, where the absence of prenatal care increased the risk of early ending of exclusive breastfeeding by $173 \%$ and the risk of discontinuing breastfeeding by $38 \% .{ }^{15}$ In Alagoas, insufficient prenatal consultations was found to increase the risk of introducing ultra-processed foods - hazard ratio (HR) 2.50; $95 \% \mathrm{CI}$ $1.02-6.16 .{ }^{16}$

Regarding rooming-in care, in the Federal District (capital of Brazil) we found that the prevalence of breastfeeding in the first hour of life was 3.5 times higher among mothers who remained with their children in the postpartum period $(83.8 \%)$. In a study conducted with low-income families in Curitiba, Paraná, it was observed that this was a protective factor for the duration of breastfeeding $(\mathrm{HR}=0.37$; 95\%CI $0.16-0.86),{ }^{18}$ showing the importance of hospital units to adapt both physically and with protocols to make this practice feasible.

In recent years, the relationship between dietary practices and childhood obesity has been widely explored in the literature, but several aspects still need clarification. ${ }^{12}$ In general, the inconsistencies identified between results

Table 2 Dietary characteristics of preschool children attending day care centers in a capital of northeastern Brazil, 2014.

\begin{tabular}{|c|c|c|c|c|}
\hline Characteristics & $n$ & $\%$ & Mean CWG (SD) & p-value \\
\hline \multicolumn{5}{|l|}{ Breastfed } \\
\hline Yes & 301 & 92.3 & $-0.03(0.9)$ & \multirow{2}{*}{0.033} \\
\hline No & 25 & 7.7 & $0.40(0.9)$ & \\
\hline \multicolumn{5}{|l|}{ Exclusive breastfeeding } \\
\hline$\leq 30$ days & 143 & 47.5 & $0.04(1.0)$ & \multirow{3}{*}{$0.385^{*}$} \\
\hline$>30$ and $\leq 180$ days & 140 & 46.5 & $-0.11(0.9)$ & \\
\hline$>180$ days & 18 & 6.0 & $-0.09(0.8)$ & \\
\hline \multicolumn{5}{|l|}{ Breastfeeding } \\
\hline$\leq 30$ days & 34 & 12.5 & $0.13(0.9)$ & \multirow{4}{*}{$0.387^{*}$} \\
\hline$>30$ and $\leq 120$ days & 56 & 20.5 & $0.08(1.0)$ & \\
\hline$>120$ days and $\leq 180$ days & 41 & 15.0 & $0.11(1.0)$ & \\
\hline$>180$ days & 142 & 52.0 & $-0.09(0.9)$ & \\
\hline \multicolumn{5}{|c|}{ Age of sugary drinks introduction } \\
\hline $0-6$ months & 32 & 9.9 & $0.12(1.0)$ & \multirow{3}{*}{$0.695^{*}$} \\
\hline 7-12 months & 140 & 43.2 & $-0.04(0.9)$ & \\
\hline$>12$ months & 152 & 46.9 & $0.01(1.0)$ & \\
\hline \multicolumn{5}{|c|}{ Age of ultraprocessed foods introduction } \\
\hline $0-6$ months & 251 & 77.2 & $-0.03(0.9)$ & \multirow{3}{*}{$0.651 *$} \\
\hline $7-12$ months & 65 & 20.0 & $0.09(1.0)$ & \\
\hline$>12$ months & 9 & 2.8 & $0.05(1.0)$ & \\
\hline
\end{tabular}

CWG: conditional weight gain; SD: standard deviation; *ANOVA. 
Table 3 Socioeconomic, gestational and perinatal characteristics of mothers of preschool children from day care centers in a capital of northeastern Brazil, 2014.

\section{Characteristics}

n

$\%$

Mother's age

\begin{tabular}{|c|c|c|c|c|}
\hline$<21$ years & 38 & 11.7 & $-0.10(0.8)$ & \multirow{2}{*}{0.506} \\
\hline$\geq 21$ years & 287 & 88.3 & $0.01(1.0)$ & \\
\hline \multicolumn{5}{|c|}{ Mother's educational level } \\
\hline$<4$ years & 45 & 13.8 & $0.03(1.1)$ & \multirow{2}{*}{0.824} \\
\hline$\geq 4$ years & 281 & 86.2 & $0.00(1.0)$ & \\
\hline \multicolumn{5}{|c|}{ Monthly per capita income } \\
\hline$\leq 70 \mathrm{BRL}$ & 27 & 8.4 & $-0.30(0.9)$ & \multirow{2}{*}{0.097} \\
\hline$>70 \mathrm{BRL}$ & 296 & 91.6 & $0.03(1.0)$ & \\
\hline \multicolumn{5}{|c|}{ Government Assistance } \\
\hline Yes & 249 & 76.6 & $0.00(1.0)$ & \multirow{2}{*}{0.850} \\
\hline No & 76 & 23.4 & $-0.01(1.0)$ & \\
\hline \multicolumn{5}{|l|}{ Planned pregnancy } \\
\hline Yes & 173 & 53.4 & $0.03(1.0)$ & \multirow{2}{*}{0.419} \\
\hline No & 151 & 46.6 & $-0.05(0.9)$ & \\
\hline \multicolumn{5}{|c|}{ Prenatal (Number of appointments) } \\
\hline$<6$ appointments & 75 & 23.0 & $0.26(1.0)$ & \multirow{2}{*}{0.008} \\
\hline$\geq 6$ appointments & 250 & 77.0 & $-0.08(0.9)$ & \\
\hline \multicolumn{5}{|l|}{ Type of delivery } \\
\hline Normal & 112 & 34.4 & $-0.07(0.9)$ & \multirow{2}{*}{0.348} \\
\hline C-section & 214 & 65.6 & $0.04(1.0)$ & \\
\hline \multicolumn{5}{|l|}{ Rooming-in Care } \\
\hline Yes & 274 & 84.3 & $-0.05(0.9)$ & \multirow{2}{*}{0.024} \\
\hline No & 51 & 15.7 & $0.28(1.0)$ & \\
\hline \multicolumn{5}{|l|}{ First child } \\
\hline Yes & 108 & 33.1 & $-0.02(0.9)$ & \multirow{2}{*}{0.717} \\
\hline No & 218 & 66.9 & $0.01(1.0)$ & \\
\hline \multicolumn{5}{|c|}{ Siblings aging $<5$ years } \\
\hline None & 235 & 72.1 & $0.00(1.0)$ & \multirow{3}{*}{$0.708^{*}$} \\
\hline 1 sibling & 81 & 24.8 & $0.00(0.8)$ & \\
\hline$\geq 2$ siblings & 10 & 3.1 & $0.25(1.2)$ & \\
\hline
\end{tabular}

CWG: conditional weight gain expressed as standard deviation; SD: standard deviation; *ANOVA.

Table 4 Factors associated with conditional weight evolution among preschool children enrolled in day care centers of the seventh sanitary district of a capital of northeastern Brazil, 2014 ( $n=320)$.

\begin{tabular}{l|c|c|c|c}
\hline Characteristics & Reference & $\beta^{*}$ & $95 \% \mathrm{Cl}$ & p-value \\
\hline Prenatal & $<6$ appointments & 0.36 & $0.13-0.60$ & 0.003 \\
\hline Rooming-in Care & No & 0.30 & $0.03-0.58$ & 0.032 \\
\hline Breastfed & Never & 0.44 & $0.06-0.81$ & 0.022
\end{tabular}

*multiple linear regression model adjusted for per capita income below the extreme poverty line, maternal age at birth, and height at the time of the survey; $95 \% \mathrm{Cl}$ : $95 \%$ confidence interval. 
can be attributed to the different types of research designs, age used as the cut-off point for discontinuation of breastfeeding, method of assessing food introduction and analytical approach.

A study conducted in municipal day care centers in Recife, Pernambuco, found that children who received exclusive breastfeeding for less than 4 months had a higher prevalence of overweight (22.5\%) compared to those who received for 4 months or more (13.5\%). Similarly, a study with children aged 12 to 24 months in Bahia showed that exclusive breastfeeding for less than 4 months was also one of the factors associated with overweight - odds ratio (OR) 2.59; 95\%CI $1.12-5.99 .{ }^{20}$

Prospective studies initiated in the prenatal or perinatal period identified a similar relationship. Huh et al. ${ }^{21}$ compared children who had never been breastfed or whose total interruption occurred before the fourth month of life with children who had been partially or exclusively breastfed until the fourth month of life. Children in the first group had a 6.3 times higher prevalence of obesity (95\%CI 2.3-16.9), but in addition to the prevalence of obesity being higher in this group $(-25 \%)$, among those who were maintained in breastfeeding the prevalence was constant $(7 \%)$, regardless of when solid foods were introduced.

Regarding the pattern of weight gain, a UK cohort found that children under three years old who received solid foods before four months of age had higher weight gain compared to those who continued on breastfeeding (CWG $=0.07$ SD; 95\%CI 0.02-0.11). ${ }^{4}$ In a similar approach, based on nationally representative data, it was found that among Brazilian children (six to 59 months), while each month of maintenance of exclusive breastfeeding had a protective effect on weight gain $(\mathrm{CWG}=-0.02 \mathrm{SD} ; 95 \%$ CI -0.03-0.00), increasing the daily frequency of sugary drinks had the opposite effect on weight gain $(\mathrm{CWG}=0.05$ SD; 95\% CI 0.02-0.08). ${ }^{5}$

One of the theories considered to elucidate the relationship between breastfeeding and obesity addresses metabolic imprinting, that is, nutritional experiences in the first thousand days of life may modulate an individual's susceptibility to the development of chronic diseases. In the case of obesity, breast milk could influence this process by changing the number and size of adipocytes and promoting neuroendocrine changes in energy balance. ${ }^{22,23}$

On the other hand, another important argument within this discussion concerns the quality of the foods offered during the introduction of complementary feeding. As observed in a previous publication with a similar sample of preschoolers, the period between the third and fifth month of life was found hold the greatest increase in probability of introducing ultra-processed foods in the child's diet. ${ }^{16}$ In this sense, the protective effect of exclusive breastfeeding would be to delay the introduction of other foods, the predominant and complementary forms limiting the volume of foods offered to the child.

However, it is noteworthy that these hypotheses are not mutually exclusive and, since overweight is established during childhood, there is an increase in the likelihood of maintaining or worsening this condition in the following stages of the life cycle, including development. of other noncommunicable chronic diseases, reduced productive capacity, disability and early death..$^{24,25}$

An important aspect to note is that all variables associated with excessive weight gain in our study are susceptible to modification, both by increasing access to health services and by professional qualification, and improving pre, peri and post-care care infrastructures. Considering the current organization of primary care, such recommendations may be of special value to professionals and health facilities involved in Rede Cegonha.

To interpret our results, it is important to consider that the cross-sectional design of the research limits the ability to make causal inferences between exposure and outcome, since one cannot be sure about the exact behavior of children's weight gain pattern; however, the arguments indicate that there is biological plausibility, coherence and consistency in the scientific literature.

Finally, there are no data available on pre-gestational nutritional status, gestational weight gain or the occurrence of gestational diabetes, factors that could be confounding the association found between weight gain and number of prenatal consultations, from the perspective that pregnant women who were seen more often by physicians could have these conditions controlled. On the other hand, as our outcome variable represents how much the child's weight gain deviated from peers, the effect of those born heavier as a result of the highlighted conditions would be adjusted.

In this population, characterized by high socioeconomic vulnerability, it can be concluded that children who never received breastfeeding, did not stay in a homestay and whose mothers attended less than six prenatal consultations had a higher than expected pattern of weight gain during childhood when compared to their peers. It is noteworthy that in the current epidemiological scenario of the Brazilian child population, with a significant reduction in the prevalence of malnutrition and an increase in obesity, such a conclusion should not be seen as a recommendation 
to promote healthy weight gain, especially regarding the introduction of formulas.

\section{Funding}

The project "Nutritional situation of children in public day care centers and actions related to food and nutrition in primary care: an intersectoral approach" was funded by the Alagoas State Research Support Foundation (FAPEAL). The author
NA was a fellow of FAPEAL. The author KS was a fellow of the National Council for Scientific and Technological Development (CNPq). The author JG was a fellow of the Coordination for the Improvement of Higher Education Personnel (CAPES).

\section{Conflict of interests}

The authors declare no conflict of interests.

\section{REFERENCES}

1. Batista Filho M, RissinA. Nutritional transition in Brazil: geographic and temporal trends. Cad Saude Publica. 2003;19:S181-91. http://dx.doi.org/10.1590/S0102-311X2003000700019

2. Silveira JA, Colugnati FA, Cocetti M, Taddei JA. Secular trends and factors associated with overweight among Brazilian preschool children: PNSN-1989, PNDS-1996, and 2006/07. J Pediatr (Rio J.). 2014;90:258-66. http://dx.doi. org/10.1016/j.jped.2013.09.003

3. Ferreira HS, LucianoSC. Prevalence of extreme anthropometric measurements in children from Alagoas, Northeastern Brazil. Rev Saude Publica. 2010;44:377-80. http://dx.doi. org/10.1590/S0034-89102010005000001

4. Griffiths LJ, Smeeth L, Hawkins SS, Cole TJ, Dezateux C. Effects of infant feeding practice on weight gain from birth to 3 years. Arch Dis Child. 2009;94:577-82. https:// doi.org/10.1136/adc.2008.137554

5. Silveira JA, Colugnati FA, Poblacion AP, Taddei JA. The role of exclusive breastfeeding and sugar-sweetened beverage consumption on preschool children's weight gain. Pediatr Obes. 2015;10:91-7. https://doi.org/10.1111/ijpo.236

6. Popkin BM, Adair LS, Ng SW. Global nutrition transition and the pandemic of obesity in developing countries. Nutr Rev. 2012;70:3-21.https://doi.org/10.1111/j.1753-4887.2011.00456.x

7. World Health Organization. WHO Anthro (version 3.2.2, January 2011) and macros [homepage on the Internet]. Geneva: WHO; 2011 [cited 2019 Apr 15]. Available from: https://www.who.int/childgrowth/software/en/

8. Cole TJ. Conditional reference charts to assess weight gain in British infants. Arch Dis Child. 1995;73:8-16. https://doi. org/10.1136/adc.73.1.8

9. World Health Organization. Nutritional anaemias: tools for effective prevention and control. Geneva: WHO; 2017.

10. Brazil - Ministério do Desenvolvimento Social e Combate à Fome. O Brasil sem miséria. Brasília: Ministério do Desenvolvimento Social e Combate à Fome; 2014.

11. Programa das Nações Unidas para o Desenvolvimento. Atlas do desenvolvimento humano no Brasil - Alagoas [homepage on the Internet]. Brasília: Programa das Nações Unidas para o Desenvolvimento; 2010 [cited 2019 Apr 15]. Available from: http://www.atlasbrasil.org.br/2013/pt/perfil_uf/alagoas
12. Woo Baidal JA, Locks LM, Cheng ER, Blake-Lamb TL, Perkins ME, Taveras EM. Risk factors for childhood obesity in the first 1,000 days: a systematic review. Am J Prev Med. 2016;50:761-79. https://doi.org/10.1016/j. amepre.2015.11.012

13. Dennis CL, Faux S. Development and psychometric testing of the Breastfeeding Self-Efficacy Scale. Res Nurs Health. 1999;22:399-409. https://doi.org/10.1002/(SICI)1098240X(199910)22:5<399::AID-NUR6>3.0.CO;2-4

14. Coca KP, Pinto VL, Westphal F, Mania PN, Abrão AC. Conjunto de medidas para o incentivo do aleitamento materno exclusivo intra-hospitalar: evidências de revisões sistemáticas. Rev Paul Pediatr. 2018;36:214-20. http://dx.doi.org/10.1590/1984-0462/;2018;36;2;00002

15. Demétrio F, Pinto EJ, Assis AM. Factors associated with early breastfeeding cessation: a birth cohort study in two municipalities in the Recôncavo region, Bahia State, Brazil. Cad Saude Publica. 2012;28:641-50. http://dx.doi. org/10.1590/S0102-311X2012000400004

16. Longo-Silva G, Silveira JA, Menezes RC, Toloni MH. Age at introduction of ultra-processed food among preschool children attending day-care centers. J Pediatr (Rio J.). 2017;93:508-16. http://dx.doi.org/10.1016/j. jped.2016.11.015

17. Sá NN, Gubert MB, Santos W, Santos LM. Factors related to health services determine breastfeeding within one hour of birth in the Federal District of Brazil, 2011. Rev Bras Epidemiol. 2016;19:509-24. http://dx.doi.org/10.1590/19805497201600030004

18. Baptista $\mathrm{GH}$, Andrade AH, Giolo SR. Factors associated with duration of breastfeeding for children of low-income families from southern Curitiba, Paraná State, Brazil. Cad Saude Publica. 2009;25:596-604. http://dx.doi.org/10.1590/ S0102-311X2009000300014

19. Balaban G, Silva GA, Dias ML, Dias MC, Fortaleza GT, Morotó FM, et al. Does breast feeding prevent childhood overweight? Rev Bras Saúde Matern Infant. 2004;4:263-8. http://dx.doi.org/10.1590/S151938292004000300006 
20. Gomes AT, Novaes TG, Silveira KC, Souza CL, Lamounier $J A$, Netto MP, et al. Excess weight and factors associated in preschool of southwest of Bahia. Rev Bras Saúde Matern Infant. 2017;17:365-73. http://dx.doi.org/10.1590/180693042017000200009

21. Huh SY, Rifas-Shiman SL, Taveras EM, Oken E, Gillman MW. Timing of solid food introduction and risk of obesity in preschool-aged children. Pediatrics. 2011;127:e544-51. http://dx.doi.org/10.1542/peds.2010-0740

22. Waterland RA, Garza C. Potential mechanisms of metabolic imprinting that lead to chronic disease. Am J Clin Nutr. 1999;69:179-97. https://doi.org/10.1093/ajcn/69.2.179
23. Balaban G, Silva GA. Efeito protetor do aleitamento materno contra a obesidade infantil. J Pediatr (Rio J.). 2004;80:7-16. http://dx.doi.org/10.1590/S0021-75572004000100004

24. Sonntag D, Ali S, De Bock F. Lifetime indirect cost of childhood overweight and obesity: A decision analytic model. Obesity (Silver Spring). 2016;24:200-6. https://doi. org/10.1002/oby.21323

25. GBD 2015 Obesity Collaborators, Afshin A, Forouzanfar MH, Reitsma MB, Sur P, Estep K, et al. Health effects of overweight and obesity in 195 countries over 25 years. N Engl J Med. 2017;377:13-27. https://doi.org/10.1056/ NEJMoa1614362 